\title{
A Study on the Awareness of Behavioral Issues of Children with Intellectual Disabilities among General Education Teachers in Inclusive Schools
}

\author{
Kumar. $\mathrm{S}^{1 *}$, Ms. David. H.B ${ }^{2}$
}

\section{ABSTRACT}

Inclusion, or organized placement of children with disabilities in mainstream classrooms, has certainly been one of the major topics in education for the last two decades. However, it was not until quite recently that teachers' attitudes towards inclusion of children with special educational needs (SENs) became the focus of extensive research. Present study was conducted with the objective to see the awareness of school teachers of Chandigarh regarding the behavioral issues of children with Intellectual disabilities. It was conducted on the 90 samples with three different teaching experience criteria and modified research questionnaire. After the analysis of data it is found that $F$ ration of the three groups found .994 , .399 and .423 respectively, which shows that $\mathrm{P}>0.05$ level. So there is no difference in the awareness of school teachers of Chandigarh regarding behavioral issues of children with ID in inclusive schools.

Keywords: Intellectual Disability, Behavioral Issues, Inclusive Schools.

Inclusion, or organized placement of children with disabilities in mainstream classrooms, has certainly been one of the major topics in education for the last two decades. However, it was not until quite recently that teachers' attitudes towards inclusion of children with special educational needs (SENs) became the focus of extensive research. The major reason for this change in research interest could perhaps be traced to more contemporary approaches to education, which claim that in order to gain valuable insight into the practice as well as the dynamics of the inclusive classroom, there is perhaps no better method than to evaluate the attitudes of those who form an important part of that dynamic system; namely, the teachers (Rose, 2001). Indeed, teachers' attitudes have been found to affect the process and the outcome of inclusion to a great extent.

\footnotetext{
${ }^{1}$ Special Educator cum Consultant, Special Education clinic, GRIID - 31, Chandigarh, India

${ }^{2}$ Nursing Professional, GRIID - 31, Chandigarh, India

*Responding Author

(C) 2016 Kumar S, David H.B; licensee IJIP. This is an Open Access Research distributed under the terms of the Creative Commons Attribution License (http://creativecommons.org/licenses/by/2.0), which permits unrestricted use, distribution, and reproduction in any Medium, provided the original work is properly cited.
} 


\section{A Study on the Awareness of Behavioral Issues of Children with Intellectual Disabilities among General Education Teachers in Inclusive Schools}

Several major initiatives have been taken internationally to support inclusive education. The United Nations Convention of 2006 on the Rights of Persons with Disabilities places an obligation on governments to ensure a fully inclusive education system for all children and forms a guideline for education systems to adopt this approach. The World Education Forum held in Dakar in April 2000 originally promoted this by establishing a goal of providing quality basic education for all children, young people, and adults by 2015. For many countries, though, they are still struggling to manage and implement an education system that justly caters for diversity (United Nations Educational Scientific Cultural Organization [UNESCO], 2008). By 2009, which is half way to achieving the Dakar goals, at least 75 million primary school-aged children have still never been to school with more than half of these living in countries affected by conflict (Save the Children, 2009).

According to the Center for Mental Health Schools (1998) in California University, the term inclusion denotes to the practice of educating children who have disabilities in classes along with their peers who do not have disabilities. Bateman and Bateman (2002) explained that the term inclusion is not a precise term because it is often confused with similar concepts such as least restrictive environment (LRE) and mainstreaming.

Unlike mainstreaming (which means moving students from separate schools and classes to regular education classes for part or all of the school day) and the LRE (which means students may receive special education and may also participate in general education setting), inclusion implies that students are needed to be taught outside the regular education classroom only when all available methods have been tried and failed to meet their needs (Bateman \& Bateman, 2002). It is a movement that seeks to create schools and other social institutions based on meeting the needs of all learners as well as respecting and learning from each other's differences (Salend, 1998). This means that the special students have the right to be educated in a general setting classroom given that a specific teaching method or approach works for him or her. In a sense, inclusionary schools should seek to establish communities of learners by educating all students together in age-appropriate, general education classrooms in their neighborhood schools (Salend \& Duhaney, 1999).

Rudd (2002) emphasized that inclusion is not to be called inclusions when there are no supports and services given to special students to help them cope in the general classroom setting. It does not also cut back special services and does not assume that all the children in the general classroom setting should learn in the same way. Rudd (2002) also emphasized that inclusion or inclusive programs should not ignore the concerns of the parents. It should also provide special education services in the general classroom and not in a separate place. 


\section{A Study on the Awareness of Behavioral Issues of Children with Intellectual Disabilities among General Education Teachers in Inclusive Schools}

The inclusion of special students in the general classroom is viewed by many researchers as advantageous in a sense that they believe special students or students with disabilities in this setting can develop better social development, better social interaction, enhanced skill acquisition and generalization, better health, more independence, greater success in meeting the objectives of their IEPs, and more normalized functioning (Burnette, 1996).

According to the research of Lipsky and Gartner (1997), inclusion can help children with disabilities reduce their fear of human differences. This is accompanied by increased comfort and awareness, growth in social cognition, improvement in self-concepts, development of personal principles, and warm and caring attitude toward peers and friends.

In another study, Moore et al (1998) found that students with moderate to severe disabilities can develop academic increases, and behavioral and social progress through inclusion. Accordingly, they found that it is not recommendable to segregate these students because in segregated sites, they do not receive a greater concentration of special education resources, degrading their traditional skills domain and social competence learning.

Almost similarly, the National Association for the Education of Young Children (1997) stated the following as advantages of inclusion to children with disabilities: demonstrate increased acceptance and appreciation of diversity; develop better communication and social skills; show better development in moral and ethical principles; create warm and caring friendship; and demonstrate increased self-esteem.

Odom et. al (1999) also preaches the good news about inclusion as their study shows that inclusion of students in general classroom settings produces positive outcomes. Parents and teachers are supportive of such program and a wide range of curricula are being used to make sure they are really effective for students with disabilities. It has also been reported that inclusion can be an advantage because it gives and ensures children with disabilities access to the general education curriculum, an important consideration in recent IDEA amendments (Council for Exceptional Children, 1998). Furthermore, inclusion can also provide opportunities for expanding social networks and forming new friendships (Scruggs \& Mastropiere, 2001).

\section{METHOD}

The researcher used the descriptive-survey method in its baseline data, which is to see the general picture of the population and the nature of its existing condition. The study was conducted in the Govt schools in Chandigarh, one of the central provinces of North India. The respondents were teachers employed in the Govt schools in Chandigarh during the school year 2013-2014. The stratified sampling method was used to include male and female general education teachers. The sampling fraction for each sector has been taken in the same proportion

(C) The International Journal of Indian Psychology, ISSN 2348-5396 (e)| ISSN: 2349-3429 (p) | 95 
as the sector has in the population. Respondents whose names fall on the inclusive odd numbers on the list of teachers in every district issued by the Chandigarh Education Department were selected from the population teachers. Current study had been conducted on 60 teachers.

\section{Instrument:}

The questionnaire was adapted from the Opinion Relative to Integration of Students with Disabilities or ORI by Antonak and Larrivee (1995). The scale is a modified version of the ORI constructed by Larrivee and Cook in 1979.

For this study, the researcher modified the ORI survey questionnaire to fit with the current study. As a result of the modifications, the researcher came up with the new research tool which is divided into two parts namely: Part 1: Profile and Part 2: Teachers' Awareness Scale towards behavioral Issues of children with ID in inclusive schools.

The researcher's research tool was validated by three experts from the Chandigarh. The validators' suggestions were incorporated to come up with the final questionnaire.

\section{Data Gathering Procedure:}

The researcher visited the Office of Educational Department to acquire the correct information regarding the number of schools and the exact number of school teachers in Chandigarh. After which, the researcher had taken the permission to conduct the study from concerned administrator.

An approval for conducting the survey was granted. The distribution of the survey questionnaire covers the all sectors of the Chandigarh. The completed questionnaires were hand scored by the researcher to avoid prejudice. After the tabulation, the results were forwarded to the statistician for treatment and analysis.

\section{RESULTS AND DISCUSSION}

Table 1: Results of one-way ANOVA-Comparison of mean scores of teachers on awareness about behavioral issues among teachers in reference to their experience.

\begin{tabular}{|l|l|r|r|r|r|c|}
\hline \multicolumn{2}{|c|}{} & \multicolumn{1}{c|}{$\begin{array}{c}\text { Sum of } \\
\text { Squares }\end{array}$} & \multicolumn{1}{c|}{ df } & \multicolumn{1}{c|}{$\begin{array}{c}\text { Mean } \\
\text { Square }\end{array}$} & \multicolumn{1}{c|}{ F } & Sig. \\
\hline $\begin{array}{l}\text { Teachers teaching } \\
\text { to Elementry } \\
\text { Students }\end{array}$ & $\begin{array}{l}\text { Between } \\
\text { Groups }\end{array}$ & 24.067 & 2 & 12.033 & .994 & $\mathrm{p}>0.05$ \\
\cline { 2 - 7 } & $\begin{array}{l}\text { Within } \\
\text { Groups }\end{array}$ & 326.900 & 27 & 12.107 & & \\
\cline { 2 - 7 } & Total & 350.967 & 29 & & & \\
\hline $\begin{array}{l}\text { Teachers Teaching } \\
\text { to the High School }\end{array}$ & $\begin{array}{l}\text { Between } \\
\text { Groups }\end{array}$ & 10.400 & 2 & 5.200 & .399 & $\mathrm{p}>0.05$ \\
\hline
\end{tabular}


A Study on the Awareness of Behavioral Issues of Children with Intellectual Disabilities among General Education Teachers in Inclusive Schools

\begin{tabular}{|c|c|c|c|c|c|c|}
\hline & & $\begin{array}{l}\text { Sum of } \\
\text { Squares }\end{array}$ & df & $\begin{array}{c}\text { Mean } \\
\text { Square }\end{array}$ & $\mathbf{F}$ & Sig. \\
\hline \multirow[t]{2}{*}{ Students } & $\begin{array}{l}\text { Within } \\
\text { Groups }\end{array}$ & 351.900 & 27 & 13.033 & & \\
\hline & Total & 362.300 & 29 & & & \\
\hline \multirow{3}{*}{$\begin{array}{l}\text { Teachers teaching } \\
\text { to the Sen. Sec. } \\
\text { level Students }\end{array}$} & $\begin{array}{l}\text { Between } \\
\text { Groups }\end{array}$ & 6.867 & 2 & 3.433 & .423 & $\mathrm{p}>0.05$ \\
\hline & $\begin{array}{l}\text { Within } \\
\text { Groups }\end{array}$ & 219.300 & 27 & 8.122 & & \\
\hline & Total & 226.167 & 29 & & & \\
\hline
\end{tabular}

Table 1 and two depict that $\mathrm{P}>0.05$ level. So there is no any difference in the awareness level of teachers regarding the behavioral issues of children with ID in inclusive schools with reference to their nature of duties and year of experience. Leyser and Tappendorf (2001) report that teachers with experience in teaching students, particularly those with special needs, intensify their confidence to teach them. This is likely to grow which invariably alters their negative attitudes. Hence Teachers teaching in Chandigarh Govt. schools perceive that their professional knowledge and skills were inadequate to effectively teach students with disabilities in regular schools.

\section{CONCLUSION}

The outcome of the present study presents the fact that there are no differences in awareness among the school teachers when grouped according to one variable i.e. years of teaching experience. It can be concluded that it is vital to consider the demographics of the respondents when there is a need to determine the attitude towards the issue. Based on the level of awareness of school teachers, there is a need to design a continuing professional development program to improve the awareness and attitude of the respondents towards inclusive education of children with Intellectual disabilities.

\section{Acknowledgments}

The author appreciates all those who participated in the study and helped to facilitate the research process.

\section{Conflict of Interests}

The author declared no conflict of interests.

\section{REFERENCES}

Alban-Metcalfe, J. \& Alban-Metcalfe, J. (2001). Managing attention deficit/hyperactivity disorder in inclusive classroom: Practical strategies for teacher. London: David Fulton.

Antonak, R. \& Larrivee, B. (1995). Psychometric analysis and revision of the Opinions Relative to Mainstreaming Scale. Exceptional Children, 62(2), 139-142. 
Avramidis, E., Bayliss, P. \& Burden, R. (2000) A survey into mainstream teachers' attitudes towards the inclusion of children with special educational needs in the ordinary school in one local authority. Educational Psychology, 20(2), 191- 211.

Bateman, D. \& Bateman, C. F. (2002). What Does a Principal Need To Know about Inclusion?ERIC Clearinghouse on Disabilities and Gifted Education Arlington VA.

Burnette, J. (1996). Including Children with Disabilities in General Education Classrooms: From Policy to Practice.

Carter, S. (2006). The development of special education services in Thailand. International Journal of Special education,21(2). Retrieved on May 31, 2012, from http://www.internationalsped.com

Corbett, J. (2000). Theories of Inclusive Education: A Student Guide. London: Chapman.

Council for Exceptional Children (1998). IDEA 1997: Let's make it work. Arlington, VA: Author. California University, LA.

Dapudong, R. (2013). Knowledge and Attitude towards Inclusive Education of Children with Learning Disabilities: The Case of Thai Primary School Teachers. Academic Research International, Vol.4 No.4, pp 496-512.

Education: Access and Quality. United Nations Ministry of Educational, Scientific and Education and Science. Cultural Organization, Spain.

Hannah, M. E. \& Pliner, S. (1983). Teacher attitudes toward handicapped children: Revised. School Psychology Review, 12(1), 17-23.

Harasymiw, S. J. \& Horne, M. D. (1976). Teacher attitudes toward handicapped children and regular class integration. Journal of Special Education, 10, 393-400.

Jenkinson J (1997). Mainstream or Special -educating students with disabilities. Routledge, UK.

Kantavong, Pennee, \& Suwaree, S. (2010). "A professional learning program for enhancing the competency of students with special needs." International Journal of Whole Schooling 6.1 53+. Academic OneFile. Web. 17.

Karagians, L. S. \& Nesbit, W. (1981). The Warnock Report: Britain's preliminary answer to P.L. 94-142. Exceptional children, 47(5), 332-336.

Larrivee, B. \& Cook, L. (1979). Mainstreaming: A study of the variables affecting teacher attitude. The Journal of Special Education, 13(3), 315-324

Leyser, Y. \& Tappendorf, K. (2001) Are attitudes and practices regarding mainstreaming changing? A case of teachers in two rural school districts, Education, 121(4), 751-761

Lipsky, D. K. \& Gartner, A. (1997). Inclusion and School Reform: Transforming America's Classrooms. Paul H. Brooke's Publishing, Baltimore MD.

Mitchell, D. (2008). What really works in special and inclusive education: Using evidencebased teaching strategies. London-New York: Routledge.

Mittler, P. (2000). Working towards inclusive education: Social Context. London: Futton.

Moore, C., Gilbreath, D. \& Maiuri, F. (1998). Educating Children with Disabilities in General Education Classrooms: A Summary of the Research. University of Oregon. 
National Association for the Education of Young Children (1997). The Benefits of Inclusive Education: Making it Work. Washington, DC.

Ochiai T. \& Jimenez L.P. (2002). Pathways for inclusion in Japan. Journal of Asia Pacific Special Education, 2(2), 85-106.

Odom, S.L., Wolery, R., Liebert, J., Sandall, S., Hanson, M. J., Beckman, P., Schwartz, I. \& Rose, R. (2001). Primary school teacher perceptions of the conditions required to include pupils with special educational needs, Educational Review, 53(2), 147-157.

Rudd, F. (2002). Grasping the Promise of Inclusion. Palm Springs, CS.

Salend, S. J. \& Garrick D. L. M. (1999). The Impact of Inclusion on Students with and Without Disabilities and Their Educators. Remedial \&Special Education; 3/1/1999

Salend, S. J. (1998). Effective mainstreaming: Creating inclusive classrooms (3rd edition). OH: Merrill/Prentice Hall.

Salend, S. J. (2008). Creating inclusive classrooms: Effective and reflective practices (6th ed.). Columbus, OH: Merrill/Pearson Education.

Save the Children. (2009). Inclusive education policy brief. Retrieved June 15, 2009, from http://www.savethechildren.org/

Scruggs, T. E. \& Mastropieri, M. (2001). Promoting inclusion in secondary classrooms. Learning Disability Quarterly, 9/22/2001

Spear-Swerling, Louise \& Lavote, R. (2006). Assessments. Retrieved: May 7, 2006. LD Online.

Stewart, R. et.al., (2001). General education and special education preserves teachers' attitudes towards inclusion. Preventing school failure. UNESCO (1994). The Salamanca Statement and Framework for Action on special Needs

United Nations Educational Scientific Cultural Organization. (2008, Spring). Policy Brief (N3). Inclusion: Halfway to Dakar - where are we? Editorial by Nicholas Burnett. Author.

United Nations. (2006). Convention on the rights of persons with disabilities. Retrieved June24, 2009, from http://www.un.org/disabilities/default.asp?navid=12\&pid=150

Yacoub, Y. (2000). Higher education and manpower planning in Lebanon.

http://www.academicjournals.org/err/pdf/pdf\%202009/apr/elzein.pdf

How to cite this article: Kumar S, David H.B (2016), A Study on the Awareness of Behavioral Issues of Children with Intellectual Disabilities among General Education Teachers in Inclusive Schools, International Journal of Indian Psychology, Volume 4, Issue 1, No. 80, ISSN:23485396 (e), ISSN:2349-3429 (p), DIP:18.01.110/20160401, ISBN:978-1-365-57867-0 